\title{
A FLIPPED CLASSROOM IN LAW TEACHING
}

\author{
M.J. Mimoso1, M.R. Anjos² \\ ${ }^{1} U P T$ - Oporto Global University; IJP (PORTUGAL) \\ ${ }^{2}$ IPMAIA - Polytechnic Institute of Maia (PORTUGAL)
}

\begin{abstract}
Globalization has introduced changes in communication between people, also affecting education in general. The intensification of the free circulation of people had generated a rethink of Higher Education. The Bologna Declaration operated a veritable "Copernican Revolution" advocating a European Higher Education Area and consequently the implementation of new teaching methodologies. In the teaching of the law there is a total absence of didactic and pedagogical training. The teaching indifference contributes to the lack of interest of students, with a negative impact on the acquisition of professional skills. We intend that this study constitutes one hand, a provocation, and the other, a critical reflection on the teaching of law in Portugal. As a result of our experience as Teachers of Higher Education in the area of Law, we implemented the flipped classroom methodology. The classroom becomes the place for teacher-student interaction, encouraging the latter to take a more active stance, collaborating in the construction of his knowledge. The results show great commitment of the student regarding this learning teaching method.
\end{abstract}

Keywords: Flipped Classroom; Globalization; Higher Education; Methodologies; Problem Based Learning (PBL).

\section{INTRODUCTION}

This theme intends to analyze the current state of law teaching in Portugal. We believe that it is reasonable to reflect on the lack of methodologies in this area of knowledge and to show our experience with the use of other methods.

We verified that most professors of Law do not have any pedagogical training, using the lecture class in constant monologue.

Thus, we have decided to experience other methodologies, mainly directed to students of the last year of the degree in Law and Solicitor.

We will not fail to highlight the poor results achieved in recent years in the examinations of access to the Bar Association, to the Solicitors and Enforcement Associations National Association and to the Center for Judicial Studies.

We emphasize the low academic performance of students, with great difficulties in writing and orality, which is reflected in the interpretation of legal texts and the acquisition of desirable legal frameworks, with visible effects, both in the evaluation and in the respective careers.

In our country the teaching of law covers two types of professors: career teachers, who embraced academic life and those who practice a full-time legal profession, teaching classes or vocation or as a salary component.

These two situations are subject to criticism. The first is its strong theoretical component, often distorted from the real world. The second with a strong emphasis on practice, but often little supported by concepts and principles underlying the legal system.

In sum, we will try to emphasize the importance of other methodologies, more proactive, capable of involving and captivating students (Oliveira, 2016).

It is necessary, as enhancer of the acquisition of knowledge, to mature on this list of problems and to look for new tools, moreover, provided by the technological revolution, especially digital. We will conclude with the analysis of Problem-Based Learning method responsible for the greater involvement of students and contribute to a better performance of the oral component, so important in the legal profession. 


\section{METHODOLOGY}

In this study we take advantage of the dialectical method.

According to the chosen object of analysis, we developed our study based on the observation of the reality that exists in our universities, in order to carry out the list of needs and systematize the most pressing ones, proceeding to a previous summary framework of the matter in question.

We also used, as a starting point, the results of the survey developed by several Authors. This article is a result of a research that consists of a systematic review, based on studies about Flipped Classroom and Problem Based Learning (PBL).

We have done a systematic review as a form of research based on the literature as a source of data, being considered capable of providing the basis for future investigations.

To obtain the analyzed articles, the descriptors "inverted classroom" and "flipped classroom" were used in the teaching of law. We have used several Databases, and we found a greater presence of authors from Latin America to reflect on the theme.

The research period included articles published between 2013 in the to 2018 .

\section{RESULTS}

\subsection{The State of Art in the Teaching of Law}

The teaching of law in Portugal is still very formal and conservative. (Teixeira, 2013)

The law is a branch of science that has low permeability change, despite the great legislative activity.

The Agency for Higher Education in Portugal (A3ES) has been emphasizing the internationalization of knowledge and research. This entity imposes criteria for the accreditation of study cycles, especially for doctoral cycles, which has also contributed to a paradigm shift in higher education.

At the same time, the Science and Technology Foundation (FCT) requires certain requirements for the qualification of university faculty, which is reflected in the evaluation of the research centers. These requirements show an evolution in the area of Law. However, these criteria are only heeded by the younger generations or senior researchers of the boldest institutions.

The change in the paradigm of higher education in the last decades did not have the necessary repercussion in the respective plans of law courses at law schools, especially at the 1st cycle of studies.

The curricula of most degrees in law remain faithful to a paradigm drawn during the dictatorship

The law faculties thus need to intensify their modernization process by introducing new curricular subjects in order to provide students with a knowledge acquisition articulated with social reality.

It appears, however, that during the 1st cycle of studies is usual to use the old scholastic methodology, expository no evidence of any contribution to the settlement of "individual cases".

Often, students become bored, disinterested in themes and do not reach their importance. In fact, a good theoretical preparation is fundamental to building a well-structured legal consciousness. This will contribute to a better analytical capacity so necessary for solving legal problems.

The question to be resolved is how to motivate students for learning the law without neglecting a sound theoretical basis of preparation?

\subsection{The teaching of law in the 21st century}

Universities should adopt methodologies that encourage students to "learn to learn" according to the paradigm of the Bologna Process (Mimoso, et al, 2018)

However, this will only be possible with the training of teachers for new methodologies. Teacher training becomes a key aspect to the learning process.

Professor centred teaching, where it is only a transmitter of knowledge, provides a distorted teaching of practical reality, not increasing the skills required by the technological age in which we live. 
Professor of higher education should aim to be a mediator of knowledge. It means that you should use techniques to help the student build his or her own knowledge.

The digital world allows content to be accessible to almost everyone. Thus, we should direct students to the search for information capable of solving concrete legal problems that they will have to solve in the future.

In short, the professor should be a guide and a discussion enhancer around the "problem." Should show the ways and possible solutions helping the student find the solution by itself. Self-learning is stimulated at the same time as the critical and analytical capacity is developed (Cintra, $n / d$ ).

This process of teaching learning should develop into two distinct moments. In the first one the student must be led to the discovery of the knowledge already instituted (theories, doctrines and jurisprudence). In the second moment the student must reflect on the factual circumstances of the case under analysis, in order to be able to design the most adequate solution to, respecting the limits imposed by the applicable law.

In other words, it is necessary to lead the student to assimilate the topics of theoretical and doctrinal reflection under analysis, in order to acquire the necessary tools for the subsequent definition of the solution of the concrete case.

The methodologies to be used in the teaching of Law must respect the judicial syllogism implicit in the solutions enshrined in the law.

This is a demanding and difficult task.

The judicial syllogism is, on the one hand, a "mediated syllogism" due to the need for a reasoning to arrive at the real conclusion. On the other hand, it is "deductive" because it is based on universal prepositions to arrive at a specific conclusion - the concrete case to be decided. Thus, the best teaching methodology will be, we believe, the one that allows to establish a connection between all the premises.

In the present work we suggest how best methodology to achieve the full legal student education, the introduction of the inverted class and the "PBL" problem-based learning.

\subsection{Flipped Classroom}

The teacher should use technology as an instrument capable of assisting the student in the teaching/learning process. An example of this modus operandi is the so-called flipped classroom (Schneiders, 2018).

Here, the student assumes an active posture, solving problems of the legal quotidian, building his knowledge.

The student must, in advance, have access to certain elements, and the faculty can make them available online, encouraging the study of certain contents. The professor, in addition to providing material, should guide the study that the student should perform (Lima, et al.2016).

In the classroom, the student, knowledgeable about the theme, can interact with the professor. This will be able to use the classroom to mediate the discussion and sedimentary knowledge about the topics involved.

All this will contribute to autonomous learning by exalting a proactive stance.

Focusing on the renewal of methodologies, it is important that the faculty plan their classes in order to enable a better articulation and interaction with the students. For example, the professor can elect some classes to present a given theme, then provides texts and/or encourages his/her research. This process ends with the presentations and debates in the classroom, previously scheduled, with the students.

\subsection{The Problem Based Learning (PBL) dynamics}

The PBL is an active teaching methodology where students get knowledge and skills while resolving problems, perfectly suited to the teaching of law, as we advocate in previous points.

As active learning, the strategy of the inverted classroom (flipped classroom), calls for the use of various strategies, as opposed to passive learning, based on the mere transmission of information. 
The student assumes a more active posture, in which he solves problems, develops projects and, with this, creates opportunities for the construction of knowledge (Valente, $n / d$ ).

Several strategies have been used to promote active learning, such as learning based on research, the use of games or "Problem Based Learning" (PBL).

This methodology is based on the development of critical thinking and problem solutions skills, being a possible tool for the methodology of the inverted classroom, especially in the teaching of law.

This methodology focused on the student, gives him/her the principal place, he/she is the protagonist of all process and encouraging knowledge through the active search for information that lacks to solve a given problem.

Education is oriented because of the problems presented. The goal is for the student to become more and more autonomous.

It is essential that students realize that the essence of their training depends on themselves.

The methodology of the PBL is considered ideal for students, already in an advanced state of knowledge, last years of study cycles, reveal an initiative to study for themselves, formulate learning objectives and undertake reading and discussion.

In the PBL the responsibility of the learning is transferred from the teacher to the student.

The acquisition of knowledge by the student is guided by the problems that are presented to him/her and that he must solve autonomously. In this process, the role of the teacher is a "counsellor" working, a guide in the learning process.

The advantages of this teaching method are better preparation for solving real problems, greater ease in the search for information, greater familiarity with the sources of information, greater ease in the application and retention of acquired knowledge and greater retention of acquired knowledge.

In other words, this is a more stimulating and interesting learning process.

\section{CONCLUSIONS}

1 The curricular plans in law remain faithful to a paradigm traced at the time of the new state. Law schools need to intensify their modernization process by introducing new curricular units in order to provide the students with a knowledge acquisition articulated with the social reality.

2 In fact, a good theoretical preparation is fundamental for the construction of a well-structured legal consciousness and the acquisition of analytical capacity for the future resolution of legal problems, of concrete cases to be decided.

The question is: how do we motivate students to learn the law without discoursing a solid theoretical base preparation?

3 Universities should adopt methodologies that encourage students to "learn to learn", incidentally, in accordance with the Bologna process paradigm.

4 The professor of higher education should seek to mediate knowledge. It means that you should use techniques to help the student build his own knowledge.

5 It is a demanding and difficult task, but possible. The judicial syllogism is based on universal prepositions to find a specific conclusion: the concrete solution to the case to be decided.

6 Thus, the introduction of the inverted class and the "PBL" problem-based learning, are the best teaching methodology to establish a connection between all these assumptions.

7 The professor should use technology as an instrument capable of assisting the student in the teaching/learning process. An example of this modus operandi is called the flipped classroom. The student assumes an active position, solving problems of the legal quotidian, building his knowledge.

8 The student must, in advance, have access to certain elements, and the faculty can make them available online, encouraging the study of certain contents and renewing methodologies, it is important that the professor plans his/her classes in order to enable a better articulation and interaction with students. 
9 The PBL is an active teaching methodology where students gain knowledge and skills while resolving problems, perfectly suited to the teaching of law, as we advocate in previous points.

10 As active learning, the strategy of the inverted classroom (flipped classroom), calls for the use of various strategies, as opposed to passive learning, based on the mere transmission of information. The student assumes a more active posture, in which he/she solves problems, develops projects and, with this, creates opportunities for the construction of knowledge.

11 The student will make his learning process through the study of the problems that are presented to him and that he must solve autonomously.

12 The role of the teacher in this system is that of student work advisor. The teaching-learning process becomes more challenging and engages students from the beginning to the end of the process.

\section{REFERENCES}

[1] Cintra, A. R. (2018). Metodologia Ativa no Ensino de Direito: uma proposta de aula invertida para a disciplina de Direito Internacional. Universidade do Oeste Paulista- UNOESTE. Available in: file:///C:/Users/user/Downloads/submissao_ATIVIDADE_4_2018-06-11-10-41-41\%20(2).pdf

[2] Lima, R.V.G. \& Holanda, M. J. (2016) UMA BREVE DISCUSSÃO SOBRE A METODOLOGIA DA AULA INVERTIDA: POSSIBILIDADES E DESAFIOS, in Revista Filosofia Capital - RFC ISSN 1982 6613, Brasília, DF. Edição Especial: As multilinguagens da educação e suas interveniências com a filosofia [...]. Vol. 11. Available in: ///C:/Users/user/Downloads/352-1166-1-PB.pdf

[3] Mimoso, M. J., Bravo, B. M. \& Gomes, J. C. (2018). The teaching of law post Bologna. Global Journal of Sociology: Current Issues. 8 (1). Available in:

http://repositorio.uportu.pt/jspui/bitstream/11328/2234/1/The\%20teaching\%20of\%20law\%20post\% 20Bologna.pdf

[4] Oliveira, E. M. (2016). Docência em Direito e a "Sala de Aula Invertida" como opção metodológica. Available in:

https://www.uniaraxa.edu.br/ojs/index.php/evidencia/article/viewFile/497/476

[5] Schneiders, L.A. (2018) O método da sala de aula invertida (flipped classroom) - Lajeado: Ed. da Univates. Available in: https://www.univates.br/editoraunivates/media/publicacoes/256/pdf_256.pdf

[6] Teixeira, G. Teixeira, G., (2013). O ensino do Direito em Portugal. Artigo de opinião. Available in: https://www.portoeditora.pt/sites/ensino-direito-portugal

[7] Valente, J. A. (n/d) Aprendizagem Ativa no Ensino Superior: a proposta da sala de aula invertida, Depto. de Multimeios, Nied e GGTE - Unicamp \& Ced - PucSP. Available in: https://www.pucsp.br/sites/default/files/img/aci/27-8_aguardar_proec_textopara280814.pdf 